\title{
Isolation of Seed-borne Fungal Endophytes on Sengon (Falcataria Moluccana )
}

\author{
Yunik Istikorini ${ }^{1 *}$ Noor Farikhah Haneda ${ }^{1}$ Ulfah Juniarti Siregar ${ }^{1}$ \\ Dhea Amelia Kusuma²
}

\author{
${ }^{1}$ Department of Silviculture, Faculty of Forestry and Environment, IPB University, Bogor, Indonesia. \\ ${ }^{2}$ Department of Plant Protection, Faculty of Agricultural, IPB University, Bogor, Indonesia. \\ *Corresponding author: yunik.istikorini@gmail.com
}

\begin{abstract}
Isolation of seed-borne fungal endophytes on sengon (Falcataria Moluccana). The purpose of this study was to compare seed-borne fungal endophytes from tolerance and susceptible sengon (Falcataria mollucana Miq) sampled from Kediri, East Jawa Province, Indonesia. Seed sampled is taken from plants that were: (1) Tolerance (showing no visual disease and pest); (2) susceptible to gall rust disease; (3) susceptible to gall rust disease and boktor pest. The result showed the diversity of seed-borne fungal endophytes isolated from susceptible plants were significantly higher than those from tolerance plants. The index value of seed-borne fungal endophytes on tolerant plants is low diversity $\left(H^{\prime}=0,6931\right)$ and on susceptible plants as moderate diversity $\left(H^{\prime}=1,0879\right.$ and 1,0645). Seed-borne fungal endophytes in tolerance plants and susceptible plants were quite different (Similarity index, $\mathrm{SC}=0$ ).
\end{abstract}

Keywords: diversity, Falcataria mollucana, fungal endophytes, seed-borne

\section{INTRODUCTION}

Endophytes live in healthy parts of plant tissue without causing disease symptoms in the host plant. Endophytes are present in all plant species. Endophytes can enter various plant organs, both in seeds, leaves, stems, and roots of plants [1,2]. The spread of endophytic fungi can be vertically through seeds. Endophytic fungi produce various secondary metabolites that can improve plant biomass and cause plants to be more resistant under biotic and abiotic pressures [3].The endophyte can directly increase plant growth, including mobilizing nutrients (e.g., phosphorus, nitrogen, and iron) and producing plant hormones. The indirect mechanisms involved antagonistic effects against pathogens [4]. Many seed-transmitted fungi are significantly affected by the local environment and host plant genotypes [3].

Sengon plant (Falcataria moluccana (Miq.) Barneby \& J. W. Grimes) is an exceptionally fastgrowing tree. It is widely grown in Indonesia, mainly as a mixed plat with industrial plantations in Java, Sumatera, Kalimantan, Sulawesi, and Nusa
Tenggara. The wood of $F$. moluccana has a high economic value, can be used such as in the pulp and paper industry, particleboard, and light construction $[5,6]$.

Falcataria moluccana was susceptible to the boktor pest (Xystrocera festiva Pascoe) and gall rust disease (Uromycladium falcatarium). The highest percentage of stem borer attacks was 90\% [5,7]. Gall rust disease has caused severe damage to all growth stages, causes damage to F. moluccana up to $90 \%$. This disease reduced the yield due to mortality and stems breakage, reduced marketability, and decreased growth rates. Therefore, it is necessary to effectively control methods for both these pests and diseases so that the losses incurred do not get bigger. The most effective and efficient control is to use resistant varieties. But until now, it has not been obtained. Endophyte microbes have been used for pest and diseases control [8]. This study aims to obtain endophytic fungal from sengon plants that are resistant and vulnerable. 


\section{MATERIALS AND METHODS}

\subsection{Isolation of seed-borne fungal endophyte}

Seed sampled were collected from Kediri, East Jawa Province, Indonesia Sengon. Seed samples used in this study from the plant that was:

1. Tolerance (showing no visual disease and pest)

2. Susceptible to gall rust disease

3. Susceptible to gall rust disease and boktor pest

The samples were disinfected with ethanol (96\%) for 30 seconds, followed by $1 \%$ sodium hypochlorite $(\mathrm{NaOCl})$ for $1 \mathrm{~min}$, and then rinsing in $70 \%$ ethanol for $1 \mathrm{~min}$, and $30 \%$ ethanol for nearly $30 \mathrm{~s}$, and finally with sterile distilled water 2-3 times. Seed materials were then dried in between folds of sterile filter papers. After sterilization, the seeds materials were placed in Petri dishes containing PDA. The plates were sealed with parafilm and incubated at room temperature $\left(27 \pm 29^{\circ} \mathrm{C}\right)$ for $2-14$ days. The incubation period for each fungus was noted. The period between the plating date until the first visual growth was considered an incubation period of growth. The fungus that grows with the same morphological

Table 1 The code of seed-borne fungal endophytes, incubation period, and the number of seed-borne fungal endophytes from tolerance and susceptible plants

\begin{tabular}{|c|c|c|c|c|}
\hline \multirow[t]{2}{*}{ Iso-late Code } & \multirow{2}{*}{$\begin{array}{c}\text { Incuba-tion period } \\
\text { (day) }\end{array}$} & \multicolumn{3}{|c|}{ Seed-borne fungal endophytes } \\
\hline & & Tolerance plants & $\begin{array}{c}\text { Plants infected gall } \\
\text { rust }\end{array}$ & $\begin{array}{c}\text { Plants infected to } \\
\text { gall rust and } \\
\text { boktor pest }\end{array}$ \\
\hline SB1 & 3 & 1 & & \\
\hline SB2 & 10 & & 1 & \\
\hline SB3 & 14 & 1 & & \\
\hline SB4 & 3 & & & 1 \\
\hline SB5 & 4 & & 1 & 1 \\
\hline SB6 & 4 & & 8 & 2 \\
\hline SB7 & 3 & & 1 & \\
\hline SB8 & 3 & & & 1 \\
\hline SB9 & 4 & & & 2 \\
\hline SB10 & 5 & & & 1 \\
\hline SB11 & 5 & & 1 & \\
\hline SB12 & 5 & & 1 & \\
\hline SB13 & 11 & & & 1 \\
\hline \multicolumn{2}{|l|}{ Total } & 2 & 13 & 9 \\
\hline \multicolumn{2}{|c|}{$\begin{array}{l}\text { Number of fungal endophytes from } \\
\text { tolerance plant }\end{array}$} & 2 & & \\
\hline \multicolumn{2}{|c|}{$\begin{array}{l}\text { Number of fungal endophytes from plants } \\
\text { infected gall rust }\end{array}$} & & 6 & \\
\hline \multicolumn{2}{|c|}{$\begin{array}{l}\text { Number of fungal endophytes from plants } \\
\text { infected gall rust and boktor pest }\end{array}$} & & & 7 \\
\hline
\end{tabular}

characteristics of colonies are considered as one genus.

\subsection{Frequency of colonization}

The frequency of endophytic fungi colonization was calculated using the formula:

$C F=\frac{N c o l}{N t} \times 100 \%$

$N_{c o l}=$ the number of segments of plant tissue colonized by each endophyte

$N_{t}=$ total number of segments studied [9].

\subsection{Diversity Index (H)}

The following formula determines the species diversity index $(\mathrm{H})$ :

$H^{\prime}=-\sum P i \log (P i)$

$$
P i=\frac{n i}{N}
$$

$\mathrm{H}^{\prime}=$ Shannon-Wienner diversity index,

$\mathrm{ni}=$ Index important values of one type or number of individuals one type

$\mathrm{N}=$ The number of indexes of important values of all types or the number of individuals of all types [10]. 


\subsection{Similarity Coefficient}

A coefficient of similarity (SC) to compare the endophyte assemblage of plant origin was calculated using the formula:

$S C=\frac{2 w}{(a+b)}$

$a=$ the sum of colonization frequency for all fungal species in a tissue,

$b=$ the similar sum for another tissue and

$w=$ the sum of lower colonization frequencies for fungal endophytes in common between the tissues [11].

\section{RESULT AND DISCUSSION}

We observed a rich diversity of seed-borne fungal endophytes associated with sengon. A total of twenty-four endophytic fungal were isolated from sengon seeds when cultured in the laboratory (Table 1). Two isolates of species were obtained from healthy plants, whereas 13 isolates from infected gall plants and nine isolates from plants infected with gall and boktor pests. Endophytic isolated from susceptible plants were significantly higher than those from resistant plants.

Each endophytic fungi incubation period varies widely, ranging from 3-14 days (Table 1). Of the four endophytic fungi isolates (SB1, SB4, SB7, and SB8) had the fastest incubation period, which was three days. Endophytic fungi isolates (SB2, SB13, and SB3) had the most extended incubation periods (10 days, 11 days, and 14 days respectively).

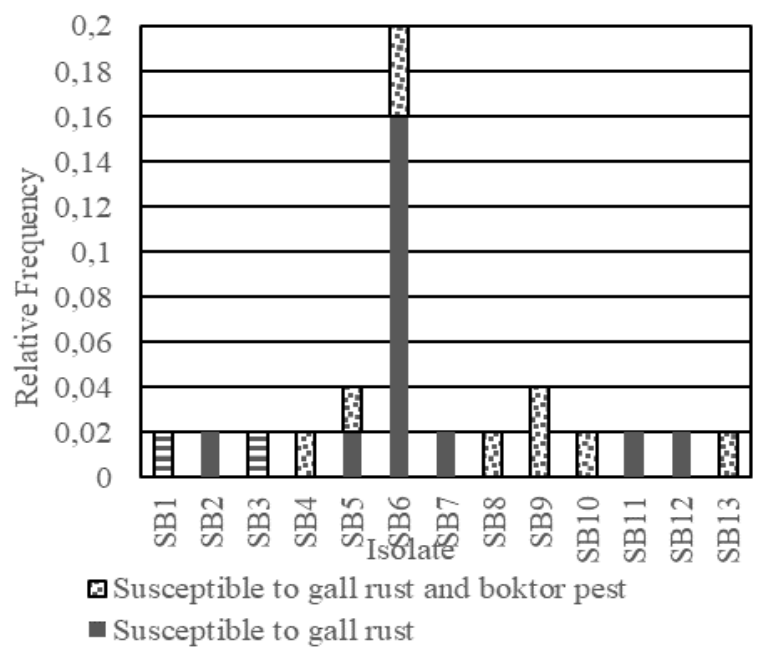

Figure 1. Frequency colonization of seed-borne fungal endophytes isolated from tolerance and susceptible plant
The species composition and the colonization frequency of the seed-borne fungal endophytes were more for the susceptible plants than tolerance plants (Figure 1). Of the 13 different species isolates, at least 11 isolates were detected to have single traits, and isolate SB6 was the dominant isolate. Plants infected with both gall rust and boktor pest containing seven different species of fungi. There were higher than seeds from susceptible gall rust plants and tolerance plants. It is suspected that niche and neutral processes are involved in the assembly of the seed microbiota [12].

\subsection{Diversity Index ( $\left.{ }^{\prime}\right)$}

Fungal endophytes from tropical trees represent the fungal biodiversity [13]. We showed the diversity analysis results based on the ShannonWiener diversity Index of seed-borne fungal endophytes from tolerance and susceptible sengon plants. The level of seed-borne fungal endophytes was higher on plant infected gall rust and boktor than that tolerant plants and plants infected with gall rust.

Table 2 The diversity index of seed-borne fungal endophytes from tolerance and susceptible sengon plants

\begin{tabular}{lc}
\hline $\begin{array}{l}\text { Origin of seed-borne fungal } \\
\text { endophytes }\end{array}$ & $\begin{array}{c}\text { Shannon-Wiener } \\
\text { diversity Index }\end{array}$ \\
\hline Tolerance plants & $0,6931(\mathrm{l})$ \\
& \\
Plants infected gall rust & $1,0879(\mathrm{~m})$ \\
Plants infected gall rust and & $1,645(\mathrm{~m})$ \\
boktor pest & \\
\hline Note: $\mathrm{l}=$ low, $\mathrm{m}=$ moderate &
\end{tabular}

The index value of seed-borne fungal endophytes on plants infected with gall rust $(1,0879)$ and plants infected with both gall rust and boktor pest $(1,645)$ is considered as moderate diversity $\left(1<\mathrm{H}^{\prime}<3\right)$. The difference in diversity of seed-borne fungal endophytes might be due to resistance differences to pests and diseases. Increased microbial diversity correlates with plant health. Plant genes are gatekeepers that encourage this diversity. The susceptible plants have more microbes than resistant plants, but the population is less diverse. Higher microbial populations in susceptible plants cause competition. The diversity of endophytic communities depends on the differences in genotype, host plant species, location, stages of the host plant growth, and the local conditions [1]. 


\section{2. $\quad$ Similarity Coefficient (Cs)}

Similarity coefficient (Cs) is needed to determine the similarity between seed-borne fungal endophytes in seed from tolerant plants and susceptible plants. We can see the similarity coefficient of endophytic fungi isolated in Table 4. There is no similarity between seed-borne fungal endophytes from tolerance plants and susceptible plants (Sorensen index, $\mathrm{SC}=0$ ). The exciting result is that they do not share identical endophytic fungi isolates. The seedborne fungal endophytes isolated from the tolerance plant were not present in the susceptible plants.

Tabel 3 Similiarity coefficient of seed-borne fungal endophytes isolated from Sengon (F. moluccana)

\begin{tabular}{lccc}
\hline Origin Plant & Tolerance & $\begin{array}{c}\text { Gall } \\
\text { rust }\end{array}$ & $\begin{array}{c}\text { Gall rust } \\
\text { and } \\
\text { boktor } \\
\text { pest }\end{array}$ \\
\hline $\begin{array}{l}\text { Tolerance } \\
\begin{array}{l}\text { Susceptible to } \\
\text { gall rust }\end{array}\end{array}$ & 1 & 1 & \\
$\begin{array}{l}\text { Susceptible to } \\
\text { gall rust and } \\
\text { boktor pest }\end{array}$ & 0 & 0,182 & 1 \\
\hline
\end{tabular}

The similarity of isolates from seeds taken from plants infected with gall rust and from seeds infected with both gall rust and boktor is 0.182 . Sorensen categorized as a low similarity. Seed-borne fungal endophytes in tolerant host plants and susceptible plants were quite different.

\section{CONCLUSION}

The diversity of seed-borne fungal endophytes isolated from susceptible plants were significantly higher than those from tolerant plants. The index value of seed-borne fungal endophytes on tolerance plants is low diversity $\left(\mathrm{H}^{\prime}=0,6931\right)$ and on susceptible sengon as moderate diversity $\left(H^{\prime}=1,0879\right.$ and 1,0645). Seed-borne fungal endophytes in tolerance plants and susceptible plants were quite different (Similarity index, $\mathrm{SC}=0$ ).

\section{REFERENCES}

[1] S. Kumar, Droby, V.K, Singh, S.K. Singh, JF. White, Entry, Colonization and Distribution of Endophytic Microorganism in Plants, in book: Kumar A., Radhakrisnan EK (Eds.), Microbial Endophytes: Functional Biology and Applications, Elsevier, India, 2020, pp. 1-33.
DOI: https://doi.org/10.1016/B978-0-12-8196540.00001-6

[2] A.N. Yadav, V. Kumar, H.S. Dhaliwal, R. Prasad, A.K. Saxena, Microbiome in Crops: Diversity, Distribution, and Potential Role in Crop Improvement, in book: R. Prasad, SS. Gill, N. Tuteja (Eds.), Crop Improvement Through Microbial Biotechnology, Elsevier, India, 2018, pp. 305-332. DOI: https://doi.org/10.1016/B9780-444-63987-5.00015-3

[3] S. Klaedtke, M.A. Jacques, L. Raggi, A. Préveaux, S Bonneau, V. Negri, Terroir is a key driver of seed-associated microbial assemblages, Environ Microbiol 18 (2016) 1792-1180. DOI: 10.1111/1462-2920.12977

[4] R. Aswani, T.N Vipina Vinod, J. Ashitha, E.K. Radhakrishnan, Benefits of Plant-Endophyte Interaction for Sustainable Agriculture, in: Kumar A., Radhakrisnan EK (Eds.), Microbial Endophytes: Functional Biology and Applications, Elsevier, India, 2020, pp. 21-33.

[5] K.S.S. Nair (ed.), Insect Pest and Diseases in Indonesia Forests: An Assessment of the Mayor Threats, Research Efforts and Literature, Center for International Forestry Research, Bogor, Indonesia, 2000, 101p. Insect pests and diseases in Indonesian forest: an assessment of the major threats, research efforts and literature - CIFOR Knowledge

[6] I. Soerianegara, RHMJ. Lemmens, Plant Resources of South-East Asia 5 (1) Timber Trees: Major Commercial Timbers. Prosea, 1993.

[7] W. Darwiyati, L. Anggraeni, Serangan Boktor (Xystrocera Festiva Pascoe) dan Karat Tumor (Uromycladium tepperianum (Sacc.) Mcalpine) pada Sengon (Falcataria Mollucana (Miq.) di Perkebunan Teh Ciater, Jurnal Sains Natural Universitas Nusa Bangsa 8(2) (2018) 59-69. [In Bahasa Indonesia]

[8] F. Gao, C. Dai, X. Liu, Review: Mechanisms of Fungal Endophytes in Plant Protection Against Pathogens, African Journal of Microbiology Research 4(13) (2010) 1346-1351. DOI: https://doi.org/10.5897/AJMR.9000480

[9] K. Hata, K Futai, Canadian Journal of Botany 73 (1995) 384-390.

[10] T.R. Parsons, M. Takahashi, B. Hargrave, Biological Oceanographic Processes, Oxford University, Oxford, 1977.

[11] G.C. Carroll, F.E. Carroll, Studies on The Incidence of Coniferous Needle Endophytes in 
The Pacific Northwest, Can. J. Bot 56(24) (1978) 3034-3043. DOI: 10.1139/b78-367

[12] A. Shade, M.A. Jacques, M. Barret, Ecological Patterns of Seed Microbiome Diversity, Transmission, and Assembly, Curr. Opin. Microbiol. 37 (2012) 15-22. DOI: 10.1016/j.mib.2017.03.010. https://www.sciencedirect.com/science/article/ab s/pii/S1369527416301576

[13]P.R. Hardoim, C.C.P. Hardoim, L.S. van Overbeek, JD. van Elsas, Dynamics of seedborne rice endophytes on early plant growth stages, PLoS ONE 7(e30438) (2012). DOI: 10.1371/journal.pone.0030438.

https://pubmed.ncbi.nlm.nih.gov/26136581/ 